\title{
Media Representation of Boko Haram in Some Nigerian Newspapers
}

\author{
Kehinde A. Ayoola ${ }^{1} \&$ Ibrahim E. Olaosun ${ }^{1}$ \\ ${ }^{1}$ Obafemi Awolowo University, Ile-Ife, Nigeria \\ Correspondence: Kehinde A. Ayoola, Obafemi Awolowo University, Ile-Ife, Nigeria. E-mail: \\ Kehinday77@yahoo.co.uk \\ Received: February 20, 2014 \\ Accepted: March 21, 2014 Online Published: May 27, 2014 \\ doi:10.5539/ijel.v4n3p49 \\ URL: http://dx.doi.org/10.5539/ijel.v4n3p49
}

\begin{abstract}
This paper examines the media representation of the socio-political discourse that centres on the activities of Boko Haram, a Nigeria-based militant Islamic group that has been responsible for violent attacks on individuals and institutions in the country. The data for the study was derived from newspaper reports published in July and August 2011 in the wake of the bombing of the nation's police headquarters and the United Nation's House in Abuja, Nigeria. The theoretical framework employed for the analysis is Critical Discourse Analysis. This interdisciplinary and inter-discursive approach made the application of historical and ideological analysis possible. The authors were able to elicit the media representation of Boko Haram as a militant Islamic group with allies and members outside Nigeria. The group is also represented as one that has an international socio-political agenda that could threaten regional peace and the continued existence of Nigeria as a peaceful and stable polity. The paper concludes that contrary to scepticisms about daily newspapers as purveyors of misery and libel, Nigerian national newspapers serve as a source of accurate information and perceptive analysis on Boko Haram, a socio-political group whose actions are inimical to public peace and Nigeria's political stability. The paper concludes that the bombing of the Nigeria Police Headquarters and the United Nations House in Abuja by the group exposed the ill-preparedness of Nigerian security agencies to meet the security challenges of the 21 st century.
\end{abstract}

Keywords: Boko Haram, ideology, Islamic theology, Nigerian press, media-political discourse

\section{Introduction}

Media discourse, according to Macdonald (2003, p. 2), frequently reacts to "perceived public desires and concerns" and sometimes sets an agenda that interacts with those of the wider society. Media analysts have favoured the concept of representation, a term that resonates with demands for objectivity and balance in news reporting and presentation of opinions in the public space. Media representation of discourse is a troublesome concept in that it suggests that there is a wide gulf between reality and its textual representation by the mass media. This is why we consider it expedient to examine connections between media discourse and a varied set of public discourses often represented in the print media. We also consider it expedient as critical discourse analysts to take a close look at both the positive and negative representations of the activities of Boko Haram, a socio-political group whose activities is inimical to the peace and stability of Nigeria, an emerging democracy. According to Bridges and Brunt (1981, p. 35), a media product is "precisely representations of the social world, images, descriptions, explanations and frames for understanding how the world is and why it works as it is said and shown to work."

The media could be described as helping to construct versions of reality in socio-political discourse. Macdonald (2003, p. 14) observes that it is pointless to argue about the accuracy of any representation of the real world in the media. This is because it is not always possible to have access to the truth and even if one does, it is often evaded or distorted by participants whose human foibles often affect their positive or negative presentation of events and happenings. She concludes that an attempt to investigate the truthfulness of media representation can produce only a wild goose chase (ibid, p. 17). Discourses are to be explored in what Foucault (1981, p. 101) describes as "tactical productivity" (the mechanics through which they achieve power) and their "strategic integration" (what circumstances and rules give rise to their use in particular circumstances). To Foucault, discourse is more than language, and it is this "extra" that binds it into social and cultural processes. Media discourse often employs language to pander to public desires, allay public fears or persuade the public to subscribe to ideological positions espoused by the ruling elite. According to Fairclough (2001, p. 50), media 
proprietors often exercise power over their consumers in that "they have sole producing rights and can therefore determine what is included or excluded" from their news reports.

Motivated by the assumption that media representation of phenomena can best be accessed through unbiased relation of such depiction to social facts, this paper considers, mainly from the linguistic perspective, the way the Nigerian print media constructs the activities of the Boko Haram group and locates their construct against Nigeria's historical, socio-cultural and ideological realities.

\section{Contextualisation and Assumptions of the Paper}

Incidents such as the 1989 fatwa against Salman Rushdie for his publication of the novel The Satanic Verses, the Oklahoma City bombing of 1989 and the bloodletting across many Islamic nations in the wake of the release of a 14-minute video on "You Tube" titled The Real Life of Mohammed by Nakoula Basseley Nakoula in July 2012, reinforced the association of Islam, through the western lens, with impulsiveness and contempt for human rights. Several other incidents such as the invasion of Kuwait by Saddam Hussein's Iraq and the activities of the Taliban in Afghanistan created conflicting views about Islam in the eyes of the international community. With the bombing of the Twin Towers of the World Trade Center by Al-Qaeda in 2001, Islamophobia became embossed on the consciousness of the free world. This incident enraged the US, who saw technology-driven, Osama bin Laden-inspired Islamic fundamentalism as a veritable threat to western civilisation. Labels such as "religious extremists" and "Islamic terrorists" became associated with Islamic militant groups. According to Macdonald (2003, p. 154), these terms have been discursively constructed by the western media to "conjure up unprovoked and irrational acts of barbarity, symptomatic of a lack of civilised values and contempt for democratic means of argument or persuasion." She writes further that terrorism in media discourse is "readily allied with a manifestation of "evil", thereby setting it within a purely moral paradigm where easy condemnation forms a ready substitute for analysis of its political formation" (ibid).

Boko Haram is the appellation of a Nigeria-based militant Islamic group originally led by Mohammed Yusuf, a charismatic Islamic cleric. The name was given to the group by residents of Maiduguri, a city in north-eastern Nigeria, because of its strong opposition to Western education, which it sees as corrupting Muslims. Founded in 2002 in Maiduguri, the capital of Borno State, Nigeria, the group's official name is Jama'atu Ahlis Sunna Lidda'awati wal-Jihad, which in Arabic means "People Committed to the Propagation of the Prophet's Teachings and Jihad". Boko Haram, translated as "Western education is forbidden", promotes a version of Islam which makes it haram (or "forbidden") for Muslims to take part in educational and social activities associated with western society. Such activities are presumed to include voting in elections, wearing shirts and trousers, and participation in secular education. Its followers are said to be influenced by the Koranic phrase, which says: "Anyone who is not governed by what Allah has revealed is among the transgressors". Mohammed Yusuf founded an Islamic school in Maiduguri, where many Muslim parents who subscribed to his ideology from across Nigeria and neighbouring countries, enrolled their children. In addition to the usual educational content and methodology of regular Islamic schools, the group also specialise in training militants. This, and several other activities and proclamations, revealed that it had political goals as well.

According to Chothia (2011), since the Sokoto caliphate, which ruled parts of what is now northern Nigeria, Niger and southern Cameroon, fell under British control in 1903,

there has been resistance among the area's Muslims to Western education. Many Muslim families still refuse to send their children to government-run "Western schools", a problem compounded by the ruling elite which does not see education as a priority. Against this background, the charismatic Muslim cleric, Mohammed Yusuf, formed Boko Haram in Maiduguri in 2002. He set up a religious complex, which included a mosque and an Islamic school.

We are inclined to agree with Chothia that Boko Haram is an opportunistic group, which though identifies with Islam, does not necessarily practice the religion in its generally accepted form. In reality, there is no verse of the Holy Quran or Hadith, the reference books of Islam, which forbids any form of education (Western or non-Western). Islam is a religion that lives on the dictates of the prophet, one of which is that all its adherents should pursue knowledge (education) even if it involves "going as far as China". The Boko Haram propaganda that Western education is forbidden is, therefore, not Islamic. The basis for the group's position is not unconnected with the fact that some Western practices run at cross-purposes, not only with major world religions, but with Nigerian cultural practices and values. What is objectionable about Boko Haram, or any group for that matter, is its attempt to impose its ideology on others.

In 2009, Boko Haram carried out a spate of attacks on police stations and other government buildings in Maiduguri. The activities of the group led to sporadic shoot-outs on Maiduguri's streets between its loyalists and 
Nigerian government forces leading to the death of hundreds of suspected Boko Haram supporters in the city. Residents flee the city in droves in the wake of the attendant unrest and prevailing atmosphere of insecurity there. Nigeria's security forces seized the group's headquarters and captured its fighters including their charismatic leader, Mohammed Yusuf. Unfortunately, Yusuf was killed in questionable circumstances while in police detention, and the gleeful parade of his corpse on national television was expected to mark the demise of the group. This and many other incidents of extra-judicial killings of members of the group is believed to have infuriated the survivors of the group and triggered a chain of reactions, which culminated in the bombing of the United Nations House in Abuja on August 26, 2011.

After the death of their mentor, the fighters regrouped under a new, unidentified and more daring leader. The group became more audacious in its operations, and it claimed responsibility for the bombing of the Nigerian police headquarters on June 16, 2011 by a suicide bomber in a bomb-laden Honda Accord car. Its modus operandi include the use of gunmen on motorbikes to attack police officers and their stations; bombing of drinking places; killing of politicians and anyone who criticises it, including Muslim and Christian clerics. It mounted a daring attack on a prison in Maiduguri in September 2010 and succeeded in freeing hundreds of the group's supporters incarcerated there. It staged several more audacious attacks in different parts of northern Nigeria between 2010 and 2011. These reportedly include a bombing in December 2010 in the city of Jos in which over 80 persons were reported dead; a New Year's Eve attack on military barracks in Abuja; and several explosions around the time of Nigeria's President Goodluck Jonathan's inauguration on May 29, 2011.

To arrest the growing trend of drive-by shootings by Boko Haram members, the authorities in Maiduguri banned the use of motorbikes in the city. According to The Punch Newspaper of August 14, 2011, over two hundred members of the sect have been arrested for various offences ranging from planting of explosives, jail breaks, and attacks against security agents. However, Nigerian government security reports published in some Nigerian newspapers revealed that the suspects could not be brought to trial because Nigerian judges feared that they and their families might become targets of violent attack by the sects if the suspects were made to appear before them. This scenario of complete breakdown of law and order ignited a feeling of fear and insecurity, not only in Maiduguri, but throughout Nigeria.

\section{Perspectives on the Nigerian Press}

O'Keeffe (2006, p. 1) describes media discourse as "the totality of how reality is represented in broadcast and printed media from television to newspaper." Ordinary members of the public buy and read the daily newspaper with great expectations of a "scoop", "breaking news", revelations of the secrets of the high and mighty, or news reports about the downfall of the "troublers" of society. The daily newspaper is viewed by many as the source of authentic information and derided by some as the purveyor of misery and libel. Notwithstanding the opposing views above, the newspaper in Nigeria is viewed as an authentic source of information about the activities of government, reports, and analysis of recent events. It is also perceived on the one hand, as the vehicle by which the ruling elite lords it over the ordinary people; and on the other hand, as a weapon by which dissident groups and political activists resist oppression and domination by the former.

Olowe (1993) views language use in Nigerian newspapers as characteristic of some deliberate manipulations of linguistic choices to meet the ideological expectations of the Nigerian audience. This view is partly corroborated by Ayoola (2008c, p. 161) who observes that no matter how hard media organisations claim to espouse balance and objectivity in their presentations, "their reporting of political issues are often slanted in favour of one of the sides". In his study on the reporting of the Niger Delta crisis in Nigerian newspapers, Ayoola (2008a, p. 3) observes that "several news items are deliberately omitted, under-reported, or over-reported by media organisations." He drew attention to the instances of abuse of media access through skilful manipulation of the public through the presentation of outright fabrications and half-truths to the reading public.

Language use in the press, according to Chiluwa (2011, p. 10), "reflects power structures in the society; hence, the structures of vocabulary and grammatical patterns in the news often demonstrate ideology and relations of power within the culture in which the language is used." In his research on the representation of the Niger Delta crisis in the Nigerian press, Chiluwa (ibid, p. 11) observes that the pattern of labelling "produces a highly negative characterisation of the key players in the crisis". He too describes the Nigerian press as a "vehicle for spreading half-truths and even propaganda" because of its supposed penchant for focusing on the activities of the Niger Delta insurgents at the expense of the "more important aspects of the Niger Delta situation, viz., unfair distribution of the oil wealth, environmental degradation, political marginalisation of the people," inter alia. This view is corroborated by Oladeinde and Ajibola (2008, p. 388), who assert that political activists from the region are consistently referred to in the Nigerian press as "militants, cultists, criminals, terrorists or kidnappers" who 
broke the Nigerian laws for selfish and personal reasons.

Going by the views expressed above, which show that the Nigerian media could not be depended upon for unbiased reporting on happenings in the country, we consider it critical to subject Nigerian newspaper reports on the activities of Boko Haram to socio-linguistic distillation. We expect that this will enable us to effectively assess the extent to which information garnered from the Nigerian print media could be used to shape public perception of the group.

\section{Ideological Representations in Media-Political Discourse}

Ideologies typically categorise people and describe society in polarised terms; hence, ideology as a notion has often been erroneously associated with the distinction between communism and capitalism during the Cold War era. However, with the manner in which individuals and groups demonstrate strong passion and commitment to socio-political causes in the wake of the cold war, the notion became even more relevant for the understanding and interpretation of media-political discourse. Macdonald (2003, p. 28) defines ideology as "a systematic framework of social understanding, motivated by a will to power, or a desire to be accepted as the "right" way of thinking, which has wide support within a particular society, or substantial social group." Eagleton (1991) asserts that it is tempting, but misleading, to regard all forms of representation as ideological. He argues that the use and application of the term should be reserved for shared ways of thinking that have a specific interest in gaining power.

According to van Dijk (2003b, p. 11), contemporary cognitive and social psychology make a distinction between many types of beliefs, viz., "personal versus social; specific versus general; concrete versus abstract; simple versus complex." He defines ideologies as socially shared beliefs, that are associated with the characteristic properties of a group, such as their identity, their position in society, their interests and aims, their relation to other groups, their reproduction, and their natural environment." Ideological representations in media-political discourse typically give rise to differences of opinion, conflict and struggle; hence, they form the basic social representations of the beliefs shared by a group, and function as a framework that defines the overall coherence of such beliefs. van Dijk (2003b) elucidates further that ideologies allow new social opinions to be easily inferred, acquired, and distributed in a group when the group and its members are confronted with new events and situations. According to him, at one level of theoretical description, ideologies are part of the minds of individuals, but at another level, they are a joint representation, distributed over the minds of the members of a group, something they have in common. A writer's ideological leaning is often reflected in his or her diction and lexical choices. For instance, racism, intolerance, and prejudice could be discerned in the description of refugees and asylum seekers in the British press as "benefit spongers", "pests", and "criminals" (van Dijk, 1992).

There is ample evidence in media-political discourse of subtle, and not so subtle, ways by which members of an influential or powerful group seek to marginalise or exclude members of weaker groups. The complicity of the media in such acts is discernible in the quantity and quality of press reports about members of a group whose ideologies are in diametrical opposition to theirs. This is often done by granting little or no space to the good deeds of the group and paying too much attention to their negative deeds and gaffs. The ideological dimension of media-political discourse is also shaped by many non-verbal practices exemplified by the presentation and analysis of photographs and videos, gestures and facial expressions, colours, emblems, and totems. Ideologies can be summarised as the group's driving force towards the reproduction of its power and the challenge of the power of its opponents or antagonists. This in effect means that if there were no conflict of goals or interests, no struggle nor competition over scarce resources, then there would be no need for ideology.

Many group ideologies, according to van Dijk (2003b, p. 24), exhibit idealised polarisations through their representation of "Self" and "Others", "Us" and "Them" to mean "we are Good and they are Bad". Consequently, lexical items are often chosen to reflect opinions or value judgments exemplified by lexical choices such as demonstration/unrest, terrorists/freedom fighter, or political struggle/civil disturbance. The above examples of ideological labels lend credence to the saying, "one man's terrorist is another man's freedom fighter." The use of such expressions is fuelled by the latent desire in us as humans to show the group we belong to in a positive light and our opponents in a negative light.

\section{The Notions of "Jihad" and "Education" in Islamic Theology}

Religious ideologies are manifest in propositions about people's relation to God. Manifest in such ideologies are fierce competition for social influence and political space. In Nigeria, for instance, Christianity and Islam are the two major competing religious ideologies on the nation's socio-political canvas. There are complex doctrines and teachings leading to distinct practices and identities between adherents of the same faith at both the secondary and tertiary levels. For instance, Moslems are not united in the different interpretations given to the Islamic 
notion of Jihad in today's contemporary society. The notion is often used in a debatable manner to describe acts of aggression by members of socio-political Moslem groups. Jihad, which is often translated as "holy war", is not exactly an aggressive concept in Islam. According to Ahmed (1992, p. 42), it is a noble and powerful concept in general Islamic practice, which literally means "struggle to realise God's will for humanity". Likewise, the expression "suicide bombing", which is used to capture the act of blowing oneself up while killing others, is not supported by any section of the Holy Quran. Indeed, the following verses of the Holy Quran forbid all forms of killing, including suicide:

For that cause We decreed for the Children of Israel that whosoever killeth a human being for other than manslaughter or corruption in the earth, it shall be as if he had killed all mankind, and whoso saveth the life of one, it shall be as if he had saved the life of all mankind. Our messengers came unto them of old with clear proofs (of Allah's sovereignty), but afterwards lo! Many of them become prodigals of the earth. (The Holy Quran, Chapter 5, p. 32)

... and do not aggress; God dislikes the aggressors. (The Holy Quran, Chapter 5, p. 87)

... You shall not kill. God has made life sacred, except in the course of justice. These are his commands to you that you may understand. (The Holy Quran, Chapter 6, p. 151)

However, some aggressors may seek justification for their actions in the verse of the Holy Quran, which reads: "... fight in the way of Allah with those who fight with you ..." (Holy Quran 2, pp. 190-191). Even this verse simply suggests that fighting or killing is allowed only in war situation or as a means of preventing being killed by aggressors. Giving this condition, it may be important to find out what constitutes a war situation for Boko Haram. Are there actions or inactions on the part of the Nigerian authorities that threaten the lives of some of its citizens, especially Muslims that hail from the northern part of the country? These and many other questions will perhaps assist the Nigerian authorities in tackling Boko Haram challenge more effectively and amicably.

Also, the position of Islam on education is clear as in the following extracts from the Holy Quran and the Hadith: "Elevated status is accorded to those who seek, possess, teach and act upon knowledge. Dismiss any thought of equality between those who know and those who do not (The Holy Quran, 39, p. 9). The following are some of the pronouncements of the Prophet Mohammed on education:

"The ink of the scholar is more sacred than the blood of the martyr."

"Seek knowledge from the cradle to the grave."

"Scholars should endeavour to spread knowledge and provide education to people who have been deprived of it."

(See Sahih Al Bukhari, Volume 2, Book 17, No. 146)

The excursion we have undertaken through the Holy Quran and the Hadith in this paper is neither to defend Islam nor castigate Boko Haram for causing fear and instability in Nigeria. The actions of Boko Haram and the reactions of the Nigerian authorities has serious implications for the growth of democracy in Nigeria; hence, our resort to CDA as the theoretical framework for the analysis of the data.

\section{The Application of Critical Discourse Analysis to Socio-Political Discourse}

Although Critical Discourse Analysis (CDA) has a linguistic basis, Blommaert (2005, p. 6) describes it as "firmly anchored in social reality and with a deep interest in actual problems and forms of inequality in societies." In the past decade or two, researchers have used the tools of CDA in their studies on racism, anti-Semitism, inequality, gender discrimination, and injustices in Europe, America, and Australia (e.g., van Dijk, 1992, 1993; Wodak, 1991; Fairclough, 1989). Mey (2001, p. 192) observes that current social discourse in the US is "blind to the issue of class, and concentrates instead on such variables as race, gender, income, education, (and lately fitness)". CDA, according to van Dijk (2003a, p. 352), is

a type of discourse analytical research that primarily studies the way social power abuse, dominance, and inequality are enacted, reproduced and resisted by text and talk in the social and political context. With such dissident research, critical discourse analysts take explicit position, and thus want to understand, expose, and ultimately resist social inequality.

CDA is interested, in a very general way, in "dominance and power relations between social entities and classes, between women and men, between national, ethnic, religious, sexual, political, cultural, and sub-cultural groups" (Titscher et al., 2000, p. 164).

CDA, being context sensitive, acknowledges that real texts are produced and disseminated in real situational 
contexts. CDA employs interdisciplinary techniques of text analysis to portray social identities, social relationships, and political ideologies. It is the duty of the discourse analyst to apply a combination of the analytical tools of linguistics with his/her knowledge and experience of the world to arrive at an empirical interpretation of a text. Critical discourse analysts, in the views of van Dijk (1993), seek to explore the role of formal structures, features or other properties of text, verbal interaction, or communicative events in the interpretation of power relations.

Critical discourse analysis seeks to forge links between mainstream linguistics and critical social theory in order to comprehend the role played by language use in asymmetrical power relations and social and political identity. It typically seeks to link the formal features of texts with social and political contexts and often broadens out the definition of text to include symbolic representations which may appear alongside the written and spoken word (Fairclough, 1992, p. 27).

Critical discourse analysts are aware of the contribution of scholarly insights to the progress and transformation of society. They are expected to conduct research in solidarity and cooperation with dominated or disgruntled groups (van Dijk, 2003a). CDA focuses mainly on social problems and political issues. More specifically, it is concerned with "the ways discourse structures enact, confirm, legitimise, reproduce, or challenge relations of power and dominance in society" (ibid). In addition to the foregoing, Fairclough and Wodak (1997) say that $\mathrm{CDA}$ is concerned with ideology and history; it engages in the mediation of links between text and society; it is interpretative and explanatory; and it is a form of social action. Since CDA is interdisciplinary and multidimensional, it cannot be pinned down to a specific theoretical framework. The aim and objectives of a research determine the analytical procedures and choice of theoretical framework.

The interdisciplinary and multi-methodological approach to discourse analysis has become popular and well-developed over the years by several scholars in the field (e.g., Wodak \& Reisigl, 2003; Fairclough, 1992, 1995; van Dijk, 1988). This approach has been found particularly ideal for CDA in that it transcends pure linguistic dimensions as it includes "more systematically, the historical, political, sociological, and/or psychological dimension in the analysis and interpretation of a specific discursive occasion" (Wodak \& Reisigl, 2003, p. 383). According to Lakoff (2003, p. 200), to do a thorough job, "the analyst must have recourse to the findings and methods of other (sub)disciplines; there is no 'discourse analysis' otherwise."

The interdisciplinary and multi-methodological approach pays attention to functions such as, "legislative, self preservation, manufacturing of public opinion, developing party internal consent, advertising and vote getting, governing as well as executing, and controlling as well as expressing opposition or dissent" (ibid.). The approach recognises that a discourse about a specific topic can find its starting point within one field of action and proceed right through to another. "Discourses cross between fields, overlap, refer to each other, or are in some other way socio-functionally linked with each other; hence, the use of terms such as 'intertextuality', 'inter-discursivity', or 'hybridity"' (Wodak \& Reisigl, 2003, p. 385). The application of the multi-methodological approach has been described as triangular or three-dimensional, and it can be summarised as follows: Analysis of linguistic features such as, lexical choices, collocational peculiarities and connotations, implications and presuppositions, syntactic coherence; analysis of intertextual and inter-discursive relationships between utterances, texts, genres and discourses; and lastly analysis of extra-linguistic variables exemplified by the place and time of the communicative event, the group's political and ideological orientation, and the historical context of the discourse (Wodak \& Reisigl, 2003, p. 383ff).

\section{Media Representation of Boko Haram as an Affiliate of Al-Qaeda}

The data for this paper was derived from news reports published in the July and August 2011 editions of three Nigerian national newspapers in the wake of the bombing of the nation's police headquarters and the United Nation's House in Abuja, Nigeria by Boko Haram. The selected newspapers, viz.: The Punch, The Nation and The Guardian, were highly visible and they were respected nationwide for the relatively high level of journalistic practice in their publications. In Extract A below, the Boko Haram is represented as an affiliate of Al-Qaeda, the militant Islamic organisation founded by the late Osama bin Laden.

\section{EXTRACT A}

The Boko Haram, after its attack on the Force [Nigeria Police] Headquarters in Abuja in June, had stated that 100 of its members had arrived from Somalia where they had gone for training. The Boko Haram spokesman, who gave his name as Usman Al-Zawahiri, said on the British Broadcasting Corporation and Voice of America that the group was responsible for the blast at the Force headquarters. He had said that Boko Haram jihadist who just returned from training in Somalia, had been sent out across the northern states of the country. [...] Somalia is one of the bases of Al-Qaeda, which was 
established by the late Osama bin Laden, who was from Saudi Arabia but was killed by US security operatives in Abbottabad, Pakistan. The group was responsible for the September 11, 2001 attacks on the World Trade Center and the Pentagon in the United States (underlining ours; The Punch, 9 July 2011, p. 3).

The Boko Haram or its members were frequently described in Nigerian national newspapers with labels that include Jihadist, militant Islamic Group, Islamic insurgents, and Muslim sect. The term Jihadist is often used in Nigerian media discourse to connote an Islamic religious extremist that is mentally conditioned to kill or be killed in the cause he believes in. Establishing a link between the Boko Haram and Al-Qaeda, a group with a reputation for carrying out daring operations even in the US, is bound to instil the feeling of profound trepidation in the heart of the Nigerian public. Somalia is a country with a media representation that can be likened to Armageddon on earth. A link with this country is a reminder of war, social upheaval, political instability, and the dreadful trio of hunger, disease, and death. That the Boko Haram chose Somalia, of all places, to train its members embosses the group on the psyche of the ordinary Nigerian as a dyed-in-the-wool anarchist group opposed to the West.

The reference to the bombing of the World Trade Center in the US by Osama bin Laden-led Al-Qaeda on September 11, 2001 is an oblique representation of the Boko Haram as either a satellite of Al-Qaeda or a militant group with access to up-to-date technical know-how in inflicting terrorist attacks on targets across the globe. This background detail explains why the group was able to infiltrate the well-guarded Nigeria Police Headquarters in Abuja, where it detonated a powerful bomb that caused the destruction of many lives and properties. But, for Providence, the explosion could have wiped out scores of police officers and security personnel, including Nigeria's Inspector General of Police, and reduced the multi-storey complex to rubbles.

\section{EXTRACT B}

There were reports on June 3, 2011 that UK spy chiefs had warned the British Prime Minister, David Cameron, that Al-Qaeda was determined to make Nigeria a base for plotting terror attacks on the West. Security Sources had said radical Islamic groups in the West African nation were dramatically stepping up their support for Boko Haram. At least 1,000 people have so far been killed by the Boko Haram insurgents in Maiduguri and other northern parts of the country. Members of the group had again on Wednesday sacked a police station in Toro, Bauchi State. They killed three soldiers of the Joint Police/Army Task Force in Maiduguri the same day (underlining ours).

Given the upsurge in the activities of suicide bombers by religious extremists all over the world, terrorism has transcended a mere national threat to a global phenomenon. Little wonder the group was able to sack a police

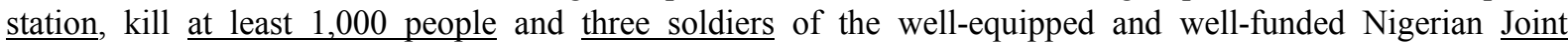

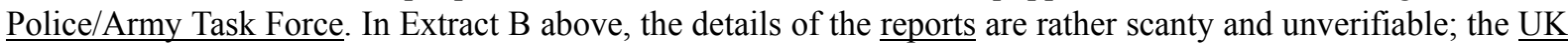
spy chiefs are not named; and the purported content of the report that Al-Qaeda was determined to make Nigeria a base for plotting terror attacks on the West could not be ascertained. On August 26, 2011, barely six weeks after the publication of the news report being analysed, and two weeks before the 10th anniversary of $9 / 11$, the Boko Haram launched a suicide bomb attack on the United Nations Headquarters in Abuja, Nigeria's capital. The attack, which completely destroyed a wing of the building, claimed at least twenty-three lives and left over seventy people with degrees of serious injury. This incident lent credence to the report by UK spy chiefs in Extract B that Al-Qaeda was determined to make Nigeria a base for plotting terror attacks on the West. Of course, the United Nations encapsulates nations from all the six continents of the world; there is a sense in which it could be seen as representing the developed West and its interests. This view is not helped by the fact that the running of the body appear to be dominated by Western powers exemplified by the US, UK, and France.

The terrorist activities of the Boko Haram group were initially restricted to the city of Maiduguri in north-eastern Nigeria and other cities in the northern part of the country. Northern Nigeria is reputed to have a predominantly Islamic population while the South has a good mix of Christians, Moslems, and animist - in that order. The use of expressions lacking in specificity such as, security sources and radical Islamic groups by the journalists conceal the identity of key participants in the conflict. The authors must have done this either to protect their source of privileged information or because they were protecting themselves or the organisation they represent from reprisal attacks from the Boko Haram or their allies. The expression, radical Islamic groups...were dramatically stepping up their support creates a picture of organised terrorist attack against the country by a coalition of Islamic fundamentalist groups both within and outside the country. While Boko Haram is seen on the surface as the enemy, it can be deduced from the report that there are many more religious extremist groups giving secret support, behind the enemy lines so to speak, to Boko Haram. Notwithstanding, the misgivings a 
critical reader may have about the origin of the news report or the scantiness of the details supplied, Boko Haram is effectively framed and represented in the discourse as a veritable threat not only to the peace and stability of Nigeria but to Europe and America.

\section{Media Representation of Boko Haram as Outlaws}

In the concluding remarks to his paper on Boko Haram uprising in Nigeria, Adesoji (2010b, p. 104) remarked aptly that "the growing problem of Islamic fundamentalism appears to be more deeply rooted than the approaches adopted by the Nigerian government to address it." Both Nigerian and the international media consistently portray Boko Haram as a socio-political group with a radical agenda that is comparable only to the Taliban of Afghanistan. The group has carried out scores of violent attacks against police establishments and personnel; government security agents; vocal political personalities; churches and mosques whose teachings and practices run contrary to its; and places where alcoholic beverages were sold and prostitution was practiced. Their beliefs and doctrines are apparently in diametrical opposition to civilized ways; hence, their violent opposition to institutions that are perceived as the bastion of western civilisation, laws, and systems of civil administration. The analysis of Extract $\mathrm{C}$ below highlights some conflicting ideological perspectives about Boko Haram's mode of operation.

\section{EXTRACT C}

A top security source said Boko Haram's claim that 100 of its members have just arrived from Somalia raised fears that they could infiltrate the country due to Nigeria's porous borders. He stated, "Boko Haram members have been travelling in and out of the country. Investigations so far have shown that some members of Boko Haram are not Nigerians. [...] Some of these aliens have criminal tendencies." [...] The Chief of Army Staff, Lt Gen. Azubuike Ihejirika, had on June 29, 2011, while expressing the army's determination to stamp out the Boko Haram menace, said “... People have to be watchful not to allow foreigners with disruptive behaviour to live among them even if they share the same culture and religion (underling ours).

Boko Haram members were variously described collectively or individually in the news report as terrorists without a cause, illegal aliens, aliens with criminal tendencies, and foreigners with disruptive behaviour. After wasting the life of yet another of its member through a suicide bomb attack launched against the United Nations House on the August 26, 2011, a Boko Haram spokesman declared on the BBC that the group still had over a hundred martyrs waiting eagerly for their opportunity to die as suicide bombers. A question that arises from this revelation is this: Do these purveyors of death and destruction perceive themselves as terrorists, aliens, or criminals? In truth, both Islam and Christian adherents in Nigeria are generally taught to respect the laws of the land, but this teaching is not visible in the actions of Boko Haram. Indeed, the group instructs its members to flout Nigerian laws in favour of what they perceived as their interpretation of the laws of Allah (God). Nigeria being a secular nation in principle, inherited most of its laws from the UK, a nation founded largely on Christian principles. However, most of the laws and decrees promulgated since independence by both military and civilian administrations in the country often take cognisance of prevailing religious and ethnic sentiments in the polity.

There is a sense in which the description of Boko Haram members as aliens and foreigners in the news report can be analysed critically. As a group that challenges the western notion of statehood and its attendant democratic practices, Boko Haram blatantly flouts Nigerian immigration laws by recruiting non-Nigerians into its fold without the mandatory entry permit or visa. The group identifies with renegade groups by training its operatives in a dissident country like Somalia, with which it shares the same culture and religion. This explains the infiltration into the country by some people from Somalia and other African countries like Niger which shares the same language, culture and religion with much of northern Nigeria. It is apparent that Boko Haram recruitment policy is guided more by Islamic fundamentalism and ideological considerations than by immigration niceties and accidents of geography. Indeed some African historians and sociologists have argued that many national boundaries in sub-Saharan Africa are arbitrary creations of colonial powers who did not take due consideration of the people's language and cultural affinities before their partitioning. The question that arises is: Should Boko Haram have respected ancient boundaries or the artificial creations by western imperialist powers that prevailed after the partitioning of Africa as recently as 1885 ?

The Nigerian newspaper report under review represents Boko Haram as a group with little or no regard for Nigerian and international laws. Although the news report describes some of its members as foreigners with disruptive behaviours, a menace, and aliens with criminal tendencies, the group is apparently not moved by this description because its activities are governed by rules other than those of democratic Nigeria and international laws. The above observation is corroborated by the fact that scores of Boko Haram members arrested by the 
Nigerian security agencies were yet to be charged to court for apparent felony and disruption of public peace. This is probably because of the fear that such an action will not only endanger the lives of Nigerian judges, but it may trigger violent reprisals capable of creating a worse embarrassment for the Nigerian government before its nationals and the international community.

\section{Conclusion}

The data was subjected to inter-discursive analysis using a combination of our knowledge of contemporary world history, Islamic and Christian practices, and Nigerian geo-politics. The analysis revealed that the Nigerian newspaper media represented Boko Haram as closely linked or allied to Al Qaeda, the cross national terrorist group, whose founder, Osama bin Laden, was killed by US security forces on May 2, 2011. Our analysis showed that Boko Haram should have been more accurately represented as a dissident socio-political group whose interpretation of Islam run at cross-purposes with the teachings of the Holy Quran and the Hadith.

Our analysis also demonstrated that the Nigerian public could rely on the Nigerian print media for accurate information and analysis of crucial socio-political happenings in the country. For instance The July 9, 2011 news report in The Punch which states that the Nigerian security agencies had received warnings on planned attacks on locations in Abuja by Boko Haram proved remarkably accurate. Consequently, an attack on the United Nations House ought to have been anticipated and adequate security measures taken by the Nigerian security agencies to forestall it. The bombing of the Nigerian Police Headquarters and the United Nations House in Abuja by suicide bombers in saloon cars exposed the incompetence and ill-preparedness of Nigerian security agencies to cope with the 21 st Century security challenges.

\section{References}

Abdullah, Y. A. (1934). Roman Transliteration of the Holy Quran with full Arabic Text. Cairo: El-Nahar Printing and Publishing Distribution.

Adesoji, A. O. (2010a). Between Maitatsine and Boko Haram. Africa Today, 57(4), 99-118. http://dx.doi.org/10.2979/africatoday.57.4.99

Adesoji, A. O. (2010b). The Boko Haram uprising and Islamic revivalism in Nigeria. African Spectrum, 45(2), 95-108.

Ahmed, A. S. (1992). Postmodernism and Islam: Predicament and Promise. London: Routledge.

Al Bukhari, S. (n.d.). Volume 2, Book 17, No. 146.

Ayoola, K. A. (2008a). A Critical Discourse Analysis of the Reporting of Some Niger-Delta Issues in Selected Nigerian Newspapers, 1999 - 2007 (Unpublished doctoral dissertation). Department of English, Obafemi Awolowo University, Ile-Ife, Nigeria.

Ayoola, K. A. (2008b). The Kaiama Declaration' and the quest for fair play in Niger Delta discourse. Papers in English and Linguistics (PEL). Linguistic Association, Obafemi Awolowo University, Ile-Ife, 9, 139-156.

Ayoola, K. A. (2008c). Objectivity and Balance in Media-political Discourse. Lagos State University Journal of Humanities, 5, 159-169.

Ayoola, K. A. (2010). The Presentation of Ideological Perspectives on Niger Delta Discourse in Nigerian Newspapers. Journal of Nigeria English Studies Association (JNESA), 13(1), 15-32.

Blommaert, J. (2005). Discourse. Cambridge: Cambridge University Press. http://dx.doi.org/10.1017/CBO9780511610295

Bridges, G., \& Brunt, R. (1981). Silver Linings: New Strategies for the Eighties. London: Lawrence and Wishart.

Chiluwa, I. (2011). Labelling and Ideology in the Press: A Corpus-based Critical Discourse Study of the Niger Delta Crisis. Frankfurt: Peter Lang.

Chotia, F. (2011). Who are Nigeria's Boko Haram Islamists? BBC African Service. Retrieved August 12, 2011, from http://www.bbc.co.uk/news/world-africa-13809501

Eagleton, T. (1991). Ideology: An Introduction. London: Verso.

Fairclough, N. (1992). Discourse and Social Change. Cambridge: Polity. http://dx.doi.org/10.1177/0957926592003002008

Fairclough, N. (1995). Critical Discourse Analysis: The Critical Study of Language. London and New York: Longman. 
Fairclough, N. (2001). Language and Power (2nd ed.). London: Longman.

Fairclough, N., \& Wodak, R. (1997). Critical discourse analysis: An overview. In T. A. van Dijk (Ed.), Discourse as Social Interaction. Discourse Studies: A Multidisciplinary Introduction (pp. 58-84). London, New Delhi and Thousand Oaks: Sage.

Forest, J. F. (2012). Confronting the Terrorism of Boko Haram in Nigeria (Joint Special Operations University Report 12-5). Florida: Joint Special Operations University Press.

Foucault, M. (1981). The History of Sexuality, Volume One: An Introduction (Translated by Robert Hurley, originally published in French as La volonte de savoir in 1976). Harmondsworth: Pelican

Lakoff, R. T. (2003). Nine ways of looking at apologies: The necessity for interdisciplinary theory and method in discourse analysis. In D. Schiffrin, D. Tannen, \& H. E. Hamilton (Eds.), The Handbook of Discourse Analysis (pp. 199-214). Oxford: Blackwell.

Macdonald, M. (2003). Exploring Media Discourse. London: Arnold.

Mey, J. L. (2001). Pragmatics: An Introduction. Oxford: Blackwell. http://dx.doi.org/10.1016/S0378-2166(01)80016-3

O’Keeffe, A. (2006). Investigating Media Discourse. New York: Routledge.

Odebode, N., Soriwei, F., \& Adepegba, A. (2011). Don't Negotiate with Boko Haram: US, EU warn FG. Saturday Punch, 9 July 2011, 3.

Oladeinde, A., \& Ajibola, M. (2008). The Dialectics of Media Framing of the Niger Delta Crisis. In E. M. Mojaye (Ed.), Media Dialogue, Peace Building and Reconciliation Conference Proceedings (pp. 387-401). Abraka: African Council for Communication Education.

Olowe, J. H. (1993). Language and Ideology in Nigerian Newspapers in the English Medium (Unpublished doctoral dissertation). Obafemi Awolowo University, Ile-Ife, Nigeria.

Soyinka, W. (2012). The butchers of Nigeria. Newsweek, 129(4), 26-27.

Talbot, M. (2007). Media Discourse: Representation and Interaction. Edinburgh: Edinburgh University Press.

Thomson, V. (2012). Boko Haram and Islamic Fundamentalism in Nigeria. Global Security Studies, 3(3), 46-60.

Titscher, S., Meyer, M., Wodak, R., \& Vetter, E. (2000). Methods of Text and Discourse Analysis. London: Sage.

van Dijk, T. (1988). News as Discourse. Hillsdale, NJ: Lawrence Erlbaum Associates.

van Dijk, T. (1992). Discourse and the denial of racism. In A. Jaworski, \& N. Coupland (Eds.), The Discourse Reader (pp. 541-558). London: Routledge.

van Dijk, T. (1993). Principles of critical discourse analysis. Discourse and Society, 4(2), 249-283. http://dx.doi.org/10.1177/0957926593004002006

van Dijk, T. (1998). Ideology. London: Sage.

van Dijk, T. (2003a). Critical discourse analysis. In D. Schiffrin, D. Tannen, \& H. E. Hamilton (Eds.), The Handbook of Discourse Analysis (pp. 352-371). Oxford: Blackwell.

van Dijk, T. (2003b). Ideology and Discourse: A Multidisciplinary Introduction (English version of an internet course for the Universitat Oberta de Catalunya). Barcelona: Ariel.

Wodak, R. (1991). Turning the tables: Antisemitic discourse in post-war Austria. Discourse and Society, 2(1), 65-84. http://dx.doi.org/10.1177/0957926591002001004

Wodak, R., \& Reisigl, M. (2003). Discourse and racism. In D. Schiffrin, D. Tannen, \& H. E. Hamilton (Eds.), The Handbook of Discourse Analysis (pp. 372-397). Oxford: Blackwell.

Youngblood-Coleman, D. (2012). Nigeria political conditions. Country Watch Inc. Retrieved March 24, 2012, from http://www.countrywatch.org

\section{Copyrights}

Copyright for this article is retained by the author(s), with first publication rights granted to the journal.

This is an open-access article distributed under the terms and conditions of the Creative Commons Attribution license (http://creativecommons.org/licenses/by/3.0/). 